\title{
A study on limnological aspects of Ramsagar lake in Dinajpur district
}

\author{
Z. Ferdoushi*, R. H. Chowdhury, K. Fatema, and A. Islam \\ Department of Fisheries Management, Hajee Mohammad Danesh Science and Technology University, Dinajpur \\ *E-mail: zannatul99bd@yahoo.com
}

\begin{abstract}
Limnological aspects of the Ramsagar lake, a manmade lake of Dinajpur district was studied from January 2013 to August 2013. In this experiment, five sampling points inside the Ramsagar lake were selected and water quality parameters were analyzed fortnightly. Among different physico-chemical parameters, water temperature, dissolved oxygen, total alkalinity, total hardness, phosphate-phosphorus and concentration of Chlorophyll-a did not differ significantly except the water level and $\mathrm{pH}$. A total of 29 species of plankton were recorded where phytoplankton comprised of 21 species and zooplankton comprised of 8 species. Chlorophyceae was found dominant throughout the study period followed by Bacillariophyceae, Cyanophyceae and Euglenophyceae. The highest plankton cell density was observed in the month of July and lowest plankton density was observed during the month of January. The study revealed that on the basis of physical, chemical, biological and environmental conditions the water of the lake was found to be suitable for survival of aquatic flora and fauna and also suitable for fish culture.
\end{abstract}

Keywords: Ramsagar lake, limnology, Water quality, Phytoplankton

\section{Introduction}

Bangladesh is one of the deltaic region countries in South-east Asia. According to Akonda (1989) nearly 7-8 million ha of wetlands do exist in Bangladesh. These include rivers, haors, baors, beels, true lakes, man-made lakes, ponds, floodplains and reservoirs. They are playing significant role in the ecology, economy and livelihood of the country. Beside fish production, some inland waterbodies (Kaptai Lake, Foy's Lake, Dhanmondi Lake, etc.) with recreational uses are also playing increasingly important role in the country economy.

Due to lack of proper guideline water quality deterioration sometime occurred in lake or ponds resulting fish mortality and spread out some contagious diseases. Moreover, major barriers in conservation of biodiversity for sustainable life in future include inadequate data base. Lack of limnological knowledge will guide confusions and controversies for proper management and conservation of a reservoir. In order to have a proper management and best possible use of a reservoir sufficient data on limnological aspects is needed. In addition, proper understanding the water quality can lead sustainable development and conservation of any aquatic ecosystem.

Raising public awareness towards the development of any water resource as well as conservation will ensure future generation to have the opportunity of enjoying the beauty of Bangladesh. In the recent years environmental scientists of the country are interested to study the limnological status of surface water bodies to assess the water quality and biodiversity for conservation planning of the wetlands (Mohuya et al. 2010; Hossain et al., 2010; Khondker et al. 2012; Islam and Chowdhury, 2013 etc.). Contamination of Dhanmondi and Gulshan lake waters was studied by Hossain et al. (2010). Aziz and Tanbir (2003) studied on phytoplankton of Ramsagar lake in Dinajpur district.

However, very few comprehensive works have been done on the limnological aspects Ramsagar lake in Dinajpur district (Aziz and Tanbir, 2003; Khondker et al., 2012). Researchers only concerned on the planktonic community of Ramsagar lake. Therefore, the present investigation has been conducted to find out the limnological status of Ramsagar lake for evaluating the potential risk of water quality deterioration of this economically important aquatic resources. 


\section{Materials and Methods}

\section{Study area}

The present study was done in Ramsagar lake of Dinajpur district, Bangladesh. The lake is around 1.03 $\mathrm{km}$ long and $0.36 \mathrm{~km}$ wide and is located on a 60 hectare elevated land which is about $8 \mathrm{~km}$ south of Dinajpur city. The main construction of Ramsagar lake was initiated by king Ram Nath between 1750 and 1755 AD. The area of the water body is 31.53 hectare which is surrounded by red color soil. Initially the reservoir was made to provide safe drinking water to local inhabitant. Now, the waterbody is playing significant recreational role in tourism. Presently the lake is taken care by the department of fisheries (DoF) (Khondker et al. 2012) and the catchment is occupied by secondary forests and managed by the forest department of Bangladesh.

For the purpose of the study, five different sampling points were selected (P1, P2, P3, P4 and P5) inside the lake (Fig. 1). Samplings were done fortnightly for a period of 8 months from January to August 2013. The water samples were collected from five different points in the morning hours between $8.0 \mathrm{am}$ to 11.0 am. Plastic bottles with stopper having a volume of $250 \mathrm{ml}$ each and marked with different point number and sampling date were used for collection of water samples. A digital thermometer was used for water temperature measurement. Transparency was measured with a secchi disc of $20 \mathrm{~cm}$ diameter. Dissolved oxygen of water samples were calculated by portable digital DO meter (Lutron, DO-5509). For observing the $\mathrm{pH}$ of water samples a direct reading digital $\mathrm{pH}$ meter (CORNING pH meter 445) was used. While other parameters such as alkalinity, hardness, phosphate and Chlorophyll-a were estimated in the laboratory of department of Fisheries Management by using standard methods as prescribed by APHA (1992) and HACH kit.

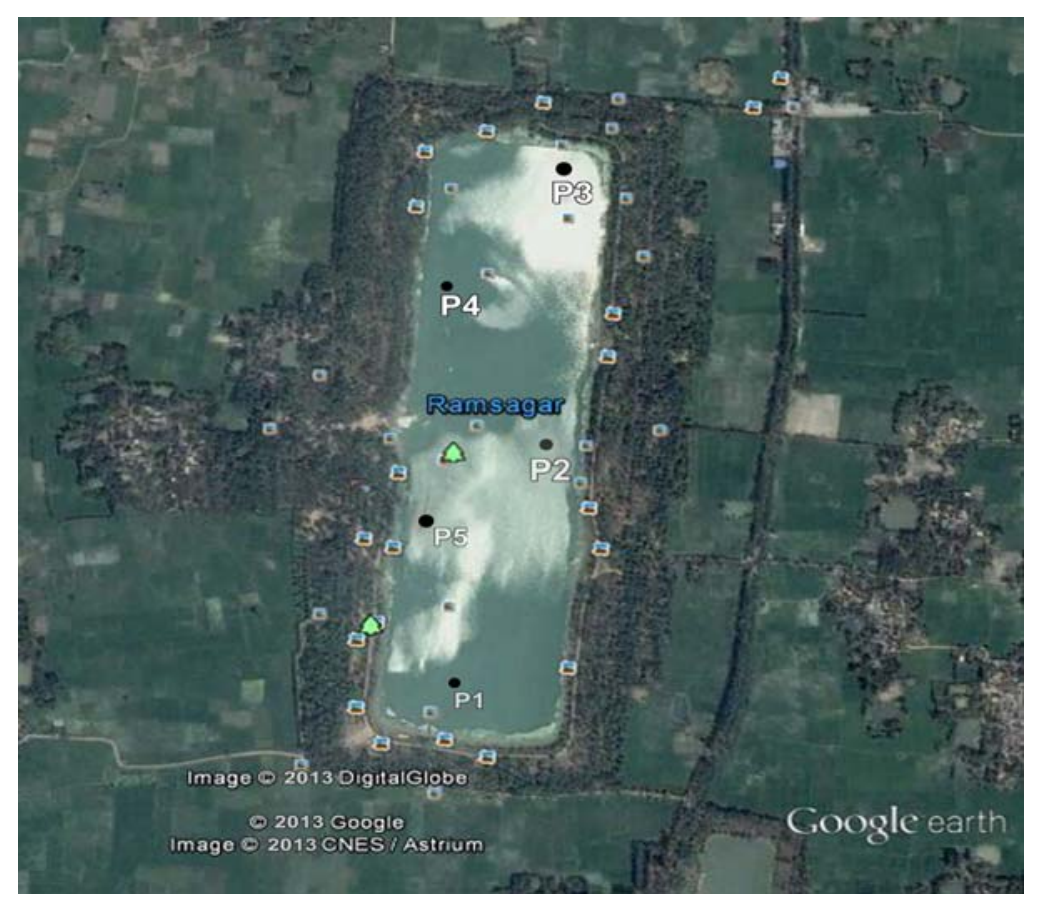

Fig. 1. Five study points of Ramsagar lake in Dinajpur district. 
Plankton samples were collected from the each point in the Ramsagar by using plankton net (mesh size, $0.04 \mathrm{~mm}$ ). Five liters of water were passed through the plankton net to get a $50 \mathrm{ml}$ sample. The sample was preserved immediately with $10 \%$ buffered formalin in a bottle. Sedgewick-Rafter (S-R cell) was used to count plankton with magnification of $10 \times 0.25$ under the binocular microscope. Taxa of plankton were identified to genus level using keys from APHA (1992). Then plankton abundance was calculated using the formula by Rahman, 1992.

$\mathrm{N}=\frac{\mathrm{A} \times 1000 \times \mathrm{C}}{\mathrm{V} \times \mathrm{F} \times \mathrm{L}}$

Where,

$\mathrm{N}=$ No. of plankton cells per liter

$A=$ Total no. of plankton counted

$\mathrm{C}=$ Volume of final concentrate of samples in $\mathrm{ml}$

$\mathrm{V}=$ Volume of a field in cubic millimeter

$\mathrm{F}=$ Number of the fields counted

$\mathrm{L}=$ Volume of original water in liter

The average number of plankton was recorded and expressed numerically per liter of water (cells/l).

\section{Statistical Analysis}

An analysis of variance (One Way ANOVA) and Tukey's test was applied to data for determining significance and comparison between means \pm SD (standard deviation). The statistical analyses were calculated by using SPSS.

\section{Results and Discussion}

\section{Physico-chemical parameters}

Table 1 is showing the mean value and ranges of different physico-chemical parameters of Ramsagar lake during the study period. Statistical analysis revealed that there was no significant difference of water quality parameter $(\mathrm{P}>0.05)$ among different sampling points except $\mathrm{pH}$ and water depth.

Rahman (1992) stated that water temperature ranging from 26.0 to $31.0^{\circ} \mathrm{C}$ was found suitable for aquatic life. The water temperature of Ramsagar lake is found suitable range throughout the study period. The mean values of water temperature found more or less similar in all points of Ramsagar lake (Table 1). The highest water temperature $\left(33.80^{\circ} \mathrm{C}\right.$ ) was observed in two points (study point 3 and 4) during the month of June and lowest $\left(16.70^{\circ} \mathrm{C}\right)$ was recorded during winter season in the month of January in point 1. Similar observation $\left(18.0\right.$ to $\left.32.0^{\circ} \mathrm{C}\right)$ was also reported by Begum et al. (2012) in another manmade lake of Gazipur district of Bangladesh. Findings were more or less similar due to the same geological position.

In the present study, the values of transparency showed variation at various sampling months, which might be due to abundance of phytoplankton. The maximum value of transparency $(79 \mathrm{~cm})$ was found in April and the lowest $(18 \mathrm{~cm}$ ) was found in March. Rahman (1992) stated the transparency of productive water bodies should be $40 \mathrm{~cm}$ or less. The transparency values were found related with the abundance of plankton.

The depth of sampling points were not much higher because of the selected points were near to the bank of the lake. The highest water depth was recorded $1.74 \mathrm{~m}$ in August and the lowest value $0.91 \mathrm{~m}$ in February. The variation of depth among different sampling points in the Ramsagar lake is due to topographic differences of the bottom of this lake and rainfall as well. 
Table 1. Mean values ( $\pm S D)$ and ranges of water quality parameters in different sampling sites throughout the period of study

\begin{tabular}{|c|c|c|c|c|c|c|}
\hline \multirow[t]{2}{*}{ Parameters } & \multicolumn{5}{|c|}{ Sampling Points } & \multirow{2}{*}{$\begin{array}{c}\text { ANOVA } \\
\text { Significance } \\
\text { (P Value) }\end{array}$} \\
\hline & Point 1 & Point 2 & Point 3 & Point 4 & Point 5 & \\
\hline $\begin{array}{l}\text { Water temperature } \\
\left({ }^{\circ} \mathrm{C}\right)\end{array}$ & $\begin{array}{c}28.49 \pm 4.99 \\
(16.70-33.70)\end{array}$ & \begin{tabular}{|c|}
$28.65 \pm 4.81$ \\
$(17.39-33.70)$
\end{tabular} & $\begin{array}{c}28.71 \pm 4.77 \\
(17.89-33.80)\end{array}$ & $\begin{array}{c}28.82 \pm 4.78 \\
(17.80-33.80)\end{array}$ & $\begin{array}{c}28.96 \pm 4.67 \\
(18.19-33.60)\end{array}$ & NS \\
\hline Transparency $(\mathrm{cm})$ & $\begin{array}{c}47.10 \pm 10.58 \\
(22-72)\end{array}$ & $\begin{array}{c}51.33 \pm 12.96 \\
(21-79)\end{array}$ & $\begin{array}{c}47.17 \pm 12.05 \\
(18-71)\end{array}$ & $\begin{array}{c}49.92 \pm 12.45 \\
(18-69)\end{array}$ & $\begin{array}{c}51.33 \pm 11.66 \\
(22-76)\end{array}$ & NS \\
\hline Depth (m) & $\begin{array}{l}1.27 \pm 0.20^{b} \\
(0.95-1.68)\end{array}$ & $\begin{array}{c}1.33 \pm 0.19^{\mathrm{ab}} \\
(0.91-1.71)\end{array}$ & $\begin{array}{c}1.27 \pm 0.17^{b} \\
(0.91-1.55)\end{array}$ & $\begin{array}{l}1.37 \pm 0.21^{\text {ab }} \\
(0.95-1.74)\end{array}$ & $\begin{array}{l}1.40 \pm 0.21^{a} \\
(0.95-1.71)\end{array}$ & * \\
\hline $\begin{array}{l}\text { Dissolved oxygen } \\
\text { (DO) }(\mathrm{mg} / \mathrm{l})\end{array}$ & $\begin{array}{c}6.86 \pm 1.00 \\
(5.10-9.90)\end{array}$ & $\begin{array}{l}6.85 \pm 0.95 \\
(5.10-9.30)\end{array}$ & $\begin{array}{l}6.59 \pm 0.81 \\
(5.10-8.80)\end{array}$ & $\begin{array}{c}6.77 \pm 0.92 \\
(5.40-9.40)\end{array}$ & $\begin{array}{c}6.79 \pm 0.85 \\
(5.40-8.80)\end{array}$ & NS \\
\hline $\mathrm{pH}$ & $\begin{array}{c}7.55 \pm 0.23^{a} \\
(7.00-7.90)\end{array}$ & $\begin{array}{l}7.43 \pm 0.33^{\text {ab }} \\
(6.53-7.91)\end{array}$ & $\begin{array}{l}7.43 \pm 0.28^{a b} \\
(7.00-8.30)\end{array}$ & $\begin{array}{c}7.40 \pm 0.19^{b} \\
(6.89-7.74)\end{array}$ & $\begin{array}{c}7.41 \pm 0.22^{b} \\
(6.94-7.84)\end{array}$ & * \\
\hline Alkalinity $(\mathrm{mg} / \mathrm{l})$ & $\begin{array}{c}14.10 \pm 3.21 \\
(8.00-20.00)\end{array}$ & $\begin{array}{c}14.72 \pm 2.97 \\
(8.00-20.00)\end{array}$ & $\begin{array}{c}14.89 \pm 2.31 \\
(8.00-19.00)\end{array}$ & $\begin{array}{c}15.10 \pm 2.44 \\
(10.00-19.00)\end{array}$ & $\begin{array}{c}15.27 \pm 2.48 \\
(10.00-19.00)\end{array}$ & NS \\
\hline Hardness (mg/l) & $\begin{array}{c}31.37 \pm 9.89 \\
(7.00-47.00)\end{array}$ & $\begin{array}{c}32.81 \pm 9.71 \\
(15.00-61.00)\end{array}$ & $\begin{array}{c}32.31 \pm 8.18 \\
(14.00-49.00)\end{array}$ & $\begin{array}{c}33.81 \pm 12.51 \\
(14.00-67.00)\end{array}$ & $\begin{array}{c}32.88 \pm 8.91 \\
(17.00-52.00)\end{array}$ & NS \\
\hline $\mathrm{PO}_{4}-\mathrm{P}(\mathrm{mg} / \mathrm{l})$ & $\begin{array}{c}0.86 \pm 0.44 \\
(0.24-1.60)\end{array}$ & $\begin{array}{c}0.76 \pm 0.38 \\
(0.24-1.60)\end{array}$ & $\begin{array}{c}0.73 \pm 0.39 \\
(0.56-1.60)\end{array}$ & $\begin{array}{c}0.82 \pm 0.33 \\
(0.56-1.60)\end{array}$ & $\begin{array}{c}0.84 \pm 0.32 \\
(0.56-1.60)\end{array}$ & NS \\
\hline $\begin{array}{l}\text { Chlorophyll a } \\
(\mu \mathrm{g} / \mathrm{l})\end{array}$ & $\begin{array}{c}104.36 \pm 86.18 \\
(11.10-267.77)\end{array}$ & $\begin{array}{c}80.35 \pm 58.10 \\
(21.42-232.07)\end{array}$ & $\begin{array}{c}94.90 \pm 74.81 \\
(11.20-255.87)\end{array}$ & $\begin{array}{c}86.11 \pm 65.20 \\
(23.70-243.97)\end{array}$ & $\begin{array}{c}74.80 \pm 48.97 \\
(11.70-166.80)\end{array}$ & NS \\
\hline
\end{tabular}

$\mathrm{NS}=$ Values are not significantly different $(P>0.05)$,

* values with different superscript letters in the same row indicate a significant difference at $5 \%$ significance level based on the oneway ANOVA followed by Tukey's test

Highest value of dissolved oxygen $(9.90 \mathrm{mg} / \mathrm{l})$ in Ramsagar lake was recorded in the month of February and the lowest value $(5.10 \mathrm{mg} / \mathrm{l})$ in the month of May. Khondker et al. (2010) found DO concentration varied between 0.61 to $11.39 \mathrm{mg} / \mathrm{l}$ at lake Bogakain, Bandarban, Bangladesh. It might be due to alteration of photosynthesis, abundance of phytoplankton, respiration by fish and other aquatic organisms of the lake. Banerjee (1967) reported that the water body having a range from 5 to $7 \mathrm{mg} / \mathrm{l} \mathrm{DO}$ is productive, while values having below this range are unproductive ones.

The $\mathrm{pH}$ value of Ramsagar lake was found acidic to alkaline ranging from 6.53 to 8.30 . Water $\mathrm{pH}$ was found mostly alkaline in point 3 during July and the lowest value was recorded in January in point 2 . However, Khondker et al. (2012) recorded pH value of Ramsagar 6.71 to 6.75 based on the analysis of a single sampling. According to Swingle (1967) $\mathrm{pH}$ value 6.5 to 9.0 is suitable for fish culture and more than 9.0 is unsuitable because free $\mathrm{CO}_{2}$ is not available in this situation. So, the $\mathrm{pH}$ of Ramsagar lake is suitable for fish culture.

Mean values of alkalinity from the study area found more or less similar in all points ranging from 8.0 to $20.0 \mathrm{mg} / \mathrm{l}$. Like $\mathrm{pH}$ the highest and lowest value of total alkalinity was also observed in the month of July and January. Total hardness was recorded 7.0 to $67.0 \mathrm{mg} / \mathrm{l}$ and the maximum and minimum value was observed in August and February, respectively. Banerjee (1967) reported that 60 to $70 \%$ of average highly productive ponds have total alkalinity ranging from 20 to $200 \mathrm{mg} / \mathrm{l}$. On the other hand, Singh et al. (2012) observed the hardness ranged (41.00 to $280.00 \mathrm{mg} / \mathrm{l}$ ) which is not agreed to the findings (7.0 to $67.0 \mathrm{mg} / \mathrm{l}$ ) of the present study. The difference between two findings might be due to applications of limestone which can cause high hardness in the water. Throughout the study, liming was not observed by the authority of Ramsagar lake. It might be the cause of low hardness values of this lake water. Clegg (1974) mentioned that lake water registering hardness as calcium carbonate below $24 \mathrm{mg} / \mathrm{l}$ is generally regarded as soft. So, it may be said that the lower concentration of hardness and alkalinity indicated the water body to be less nutrient enriched. Moreover, the water of Ramsagar lake was found as soft-medium hard type and moderately productive. 
The value of $\mathrm{PO}_{4}-\mathrm{P}$ was recorded 0.24 to $1.60 \mathrm{mg} / \mathrm{l}$ during the study period. Islam and Saha (1975) observed that $\mathrm{PO}_{4}-\mathrm{P}$ ranges from 0.2 to $2.8 \mathrm{mg} / \mathrm{l}$ were favorable for growth of phytoplankton like blue green algae and diatoms. The highest $(267.77 \mu \mathrm{g} / \mathrm{l})$ number of Chlorophyll-a was found in January and lowest $(11.10 \mu \mathrm{g} / \mathrm{l})$ in March. Chlorophyll concentration found to vary with the nutrient availability and plankton concentration.

\section{Plankton abundance}

A total of 29 genera of plankton were identified from Ramsagar lake. Table 2 is showing the mean values and ranges of different plankton groups in five sampling sites. Fortnightly variations in abundance of different plankton groups of Ramsagar lake are shown in Fig. 2 (a-f). Statistical analysis revealed no significant difference $(P>0.05)$ among different planktonic groups from five sampling points. Total phytoplankton was highest $\left(57.83 \times 10^{3}\right.$ cells/l) in $\mathrm{P} 5$ in July and lowest $\left(16.11 \times 10^{3}\right.$ cells/l) in $\mathrm{P} 1$ in January (Fig. 2e).

Table 2. Mean values $( \pm S D)$ and range of biological parameters in different sampling points throughout the period of study

\begin{tabular}{|l|c|c|c|c|c|}
\hline \multirow{2}{*}{$\begin{array}{l}\text { Plankton } \\
\text { Groups }\end{array}$} & \multicolumn{5}{|c|}{ Sampling Points } \\
\cline { 2 - 6 } Euglenophyceae & $1.18 \pm 0.84$ & $1.52 \pm 0.77$ & $1.35 \pm 0.95$ & $1.31 \pm 0.78$ & $1.44 \pm 0.88$ \\
& $(0.34-4.42)$ & $(0.35-3.8)$ & $(0.00-4.42)$ & $(0.00-3.27)$ & $(0.00-3.90)$ \\
\hline Cyanophyceae & $6.38 \pm 3.15$ & $8.03 \pm 4.17$ & $7.47 \pm 3.55$ & $7.97 \pm 4.24$ & $7.91 \pm 3.42$ \\
& $(0.32-13.26)$ & $(1.36-15.54)$ & $(2.22-14.04)$ & $(1.36-18.700$ & $(1.99-16.50)$ \\
\hline Bacillariophyceae & $8.06 \pm 3.71$ & $8.04 \pm 3.79$ & $9.13 \pm 5.27$ & $9.19 \pm 5.67$ & $8.08 \pm 4.59$ \\
& $(4.68-19.76)$ & $(3.33-21.23)$ & $(4.32-26.21)$ & $(2.79-27.21)$ & $(2.59-23.45)$ \\
\hline Chlorophyceae & $10.81 \pm 4.37$ & $12.48 \pm 4.44$ & $11.29 \pm 4.32$ & $11.32 \pm 4.59$ & $10.57 \pm 4.53$ \\
& $(4.76-19.45)$ & $(5.61-22.21)$ & $(5.76-21.56)$ & $(3.60-22.13)$ & $(5.18-22.20)$ \\
\hline Total Phytolankton & $26.43 \pm 9.06$ & $30.11 \pm 8.32$ & $29.26 \pm 10.47$ & $29.76 \pm 10.81$ & $28.17 \pm 11.98$ \\
& $(12.92-45.39)$ & $(14.38-50.61)$ & $(16.92-56.61)$ & $(15.84-52.13)$ & $(13.68-60.02)$ \\
\hline Copepoda & $0.79 \pm 0.44$ & $0.91 \pm 0.36$ & $0.79 \pm 0.46$ & $0.66 \pm 0.43$ & $1.14 \pm 0.50$ \\
& $(0.00-1.90)$ & $(0.00-1.48)$ & $(0.00-1.80)$ & $(0.00-1.44)$ & $(0.00-2.20)$ \\
\hline Rotifera & $0.82 \pm 0.40$ & $0.71 \pm 0.46$ & $0.84 \pm 0.49$ & $0.78 \pm 0.51$ & $1.01 \pm 0.64$ \\
& $(0.00-1.52)$ & $(0.00-1.8)$ & $(0.00-1.6)$ & $(0.00-1.40)$ & $(0.00-2.22)$ \\
\hline Cladocera & $0.40 \pm 0.32$ & $0.41 \pm 0.32$ & $0.46 \pm 0.47$ & $0.52 \pm 0.40$ & $0.35 \pm 0.31$ \\
& $(0.00-1.14)$ & $(0.00-1.11)$ & $(0.00-1.70)$ & $(0.00-1.7)$ & $(0.00-1.17)$ \\
\hline Crustaceae & $1.33 \pm 0.46$ & $1.24 \pm 0.46$ & $1.13 \pm 0.35$ & $1.23 \pm 0.44$ & $1.20 \pm 0.36$ \\
& $(0.37-1.90)$ & $(0.37-2.22)$ & $(0.37-1.90)$ & $(0.00-1.90)$ & $(0.37-1.95)$ \\
\hline Total Zooplankton & $3.34 \pm 0.84$ & $3.29 \pm 0.80$ & $3.16 \pm 0.89$ & $3.20 \pm 0.83$ & $3.70 \pm 0.78$ \\
& $(1.11-4.50)$ & $(1.85-5.67)$ & $(1.38-5.44)$ & $(1.45-4.88)$ & $(1.65-5.21)$ \\
\hline Total Plankton & $29.63 \pm 9.29$ & $33.40 \pm 8.63$ & $32.42 \pm 10.62$ & $32.96 \pm 11.03$ & $31.87 \pm 11.80$ \\
& $(15.85-49.05)$ & $(16.86-53.87)$ & $(19.95-59.64)$ & $(19.08-55.88)$ & $(17.44-61.79)$ \\
\hline
\end{tabular}

Chlorophyceae was the dominant group in terms of diversity and numbers followed by Bacillariophyceae, Cyanophyeeae and Euglenophyeeae. Euglenophyeeae was found least abundant group. Chlorophyceae consisted of 8 genus such as Ceratium, Coelestrum, Stigeoclonium, Pediastrum, Scenedesmus, Staurastrum, Ulothrix and Zygnema, Bacillariophyceae consisted of 5 species such as Cosmarium, Cyclotella, Fragillaria, Navicula and Asterionella, Cyanophyceae included Anabaena, Gloeocapsa, Microcyctis, Nostoc, Oscillatoria, Spirulina and Gloeotrichia and Euglenophyceae included 1 genus Euglena (Table 3). Similar observation was also made by Das et al. (2011) in oxbow lake in Assam. 
Table 3. Composition and distribution of plankton in Ramsagar lake all over the study period

\begin{tabular}{|c|c|c|c|c|c|}
\hline \multirow{2}{*}{$\begin{array}{l}\text { Phytoplankton } \\
\text { groups }\end{array}$} & \multicolumn{5}{|c|}{ Sampling points } \\
\hline & P1 & P2 & P3 & P4 & P5 \\
\hline \multicolumn{6}{|l|}{ Euglenophyceae } \\
\hline Euglena & * & * & $\star \star \star$ & * & * \\
\hline \multicolumn{6}{|l|}{ Cyanophyceae } \\
\hline Anabaena & * & * & 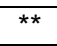 & * & * \\
\hline Gloeocapsa & $\star \star$ & * & $\star \star$ & * & * \\
\hline Microcystis & 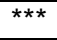 & ** & ** & 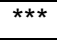 & ** \\
\hline Nostoc & 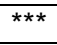 & ** & 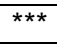 & $\star \star$ & ** \\
\hline Oscillatoria & * & * & * & $\star \star$ & * \\
\hline Spirulina & ** & ** & 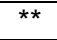 & 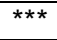 & ** \\
\hline Gloeotrichia & * & * & * & * & * \\
\hline \multicolumn{6}{|l|}{ Baciilariophyceae } \\
\hline Cosmarium & $\star \star$ & ** & $\star \star$ & * & 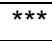 \\
\hline Cyclotella & ** & 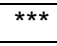 & $\star \star$ & 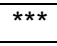 & 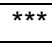 \\
\hline Fragillaria & * & * & * & * & * \\
\hline Navicula & - & * & * & * & * \\
\hline Asterionella & * & * & * & * & * \\
\hline \multicolumn{6}{|l|}{ Chlorophyceae } \\
\hline Ceratium & ** & ** & 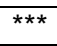 & $\star \star$ & ** \\
\hline Coelastrum & * & * & $\star \star$ & * & * \\
\hline Stigeoclonium & * & * & * & * & * \\
\hline Pediastrum & ** & ** & ** & ** & ** \\
\hline Scenedesmus & - & * & - & - & * \\
\hline Staurastrum & $\star \star \star *$ & $\star \star \star *$ & 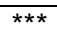 & $\star \star \star \star$ & 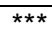 \\
\hline Ulothrix & * & $\star \star$ & $\star \star$ & $\star \star$ & * \\
\hline Zygnema & - & - & - & * & * \\
\hline \multicolumn{6}{|l|}{ Copepoda } \\
\hline Cyclops & $\star \star \star$ & ** & $\star \star$ & $\star \star$ & $\star \star$ \\
\hline Diaptomus & * & - & ** & $\star \star$ & * \\
\hline Calanus & - & - & * & - & - \\
\hline \multicolumn{6}{|l|}{ Rotifera } \\
\hline Asplancha & ** & ** & ** & ** & ** \\
\hline Brachious & $\star \star$ & ** & $\star \star$ & * & * \\
\hline Keratella & * & * & * & * & * \\
\hline \multicolumn{6}{|l|}{ Cladocera } \\
\hline Daphnia & * & * & * & * & - \\
\hline \multicolumn{6}{|l|}{ Crustacea } \\
\hline Nauplius & $\star \star \star \star ~$ & *夫 & $\star \star$ & 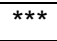 & ** \\
\hline
\end{tabular}

- = Absent; * = Rare; ${ }^{\star *}=$ Common, ${ }^{\star \star *}=$ Dominant

Average fortnightly variations in abundance of total zooplankton are shown in Fig. 2.f. A Total of 8 genera of zooplankton were observed such as Cyclops, Diaptomus, Calanus, Asplancha, Brachionus, Keratella, Daphnia and Nauplius belonging two groups crustacea and rotifera. Crustacea was the most dominant group followed by rotifera. However. Ahmed et al. (1992) found rotifera was the most dominant group followed by copepoda and cladocera in Kaptai lake of Bangladesh. The highest average number of zooplankton was found in August and the lowest average number in January (Fig. 2 f). Islam et al. (2001), Arora (1966) and Bergins (1949) designated a large number of rotifers genera including Barchionus sp., Keratella sp., Filinia sp. Gastropus sp., Hexarthra sp., Polyarthra sp., Trichocerca sp. and others as indicators of eutrophic or polluted waters. However, results of the present findings are more or less similar to the above investigation. The relative abundance of different planktonic groups indicating that the water of Ramsagar lake is highly productive and no such types of noxious algal bloom was detected. 

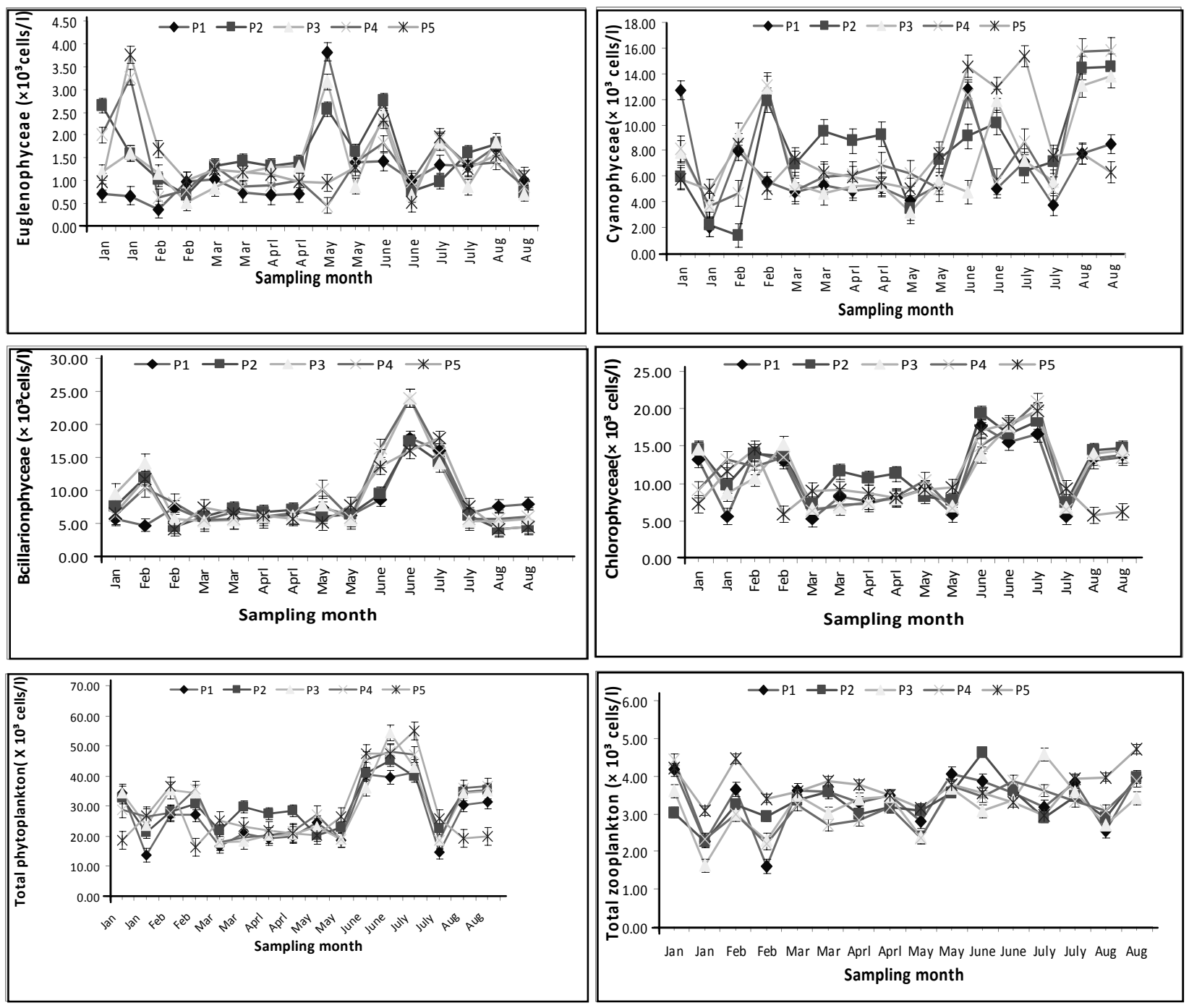

Fig. 2. Fortnightly variations in abundance of plankton in five points: a. Euglenophyceae, b. Cyanophyceae, c. Bacillariophyceae, d. Chlorophyceae e. Total phytoplankton f. Total zooplankton

\section{Conclusion}

The limnological status of Ramsagar lake indicates that lake is conducive to enhanced fisheries and biological production as well. However, some conservation measures must be taken by the government to protect the lake from environmental pollution from tourism. Moreover, long-term study would be necessary to study the impacts related to increasing access to tourists for picnics.

\section{Acknowledgements}

The authors would like to thank UGC (University Grant Commission) for the financial support and Department of Forest, Ministry of Land for kind co-operation during the research work. 


\section{References}

Ahmed, K.K., Halder, G.C. and Saha, S. B. 1992. Limnological studies on Kaptai lake. Final Report. Fisheries Research Institute, Kiverine sub-station, Rangamati, Bangladesh $36 \mathrm{pp}$.

Akonda, A. W. 1989. Bangladesh. In: A directory of Asian Wetlands, Scott DA (Ed.), pp. 541-581. IUCN, Switzerland and Cambridge.

APHA. 1992. Standard Methods for the Examination of water and Waste water. $18^{\text {th }}$ ed, American Public Health Association, Washington DC. p. 1268.

Arora, H. C. 1966. Rotifer as indicators of trophic nature of environment. Hydrobiologia, 32(1-2): 146-159.

Aziz, A. and Tanbir, M. 2003. Algal flora of some northern districts of Bangladesh. Bangladesh J. Plant Taxon., 10(1): 63-78.

Banerjee, S. M. 1967. Water quality and soil condition of fish ponds in some states of India in relation to fish production. Indian J. Fish., 14: 115-144.

Begum, R., Khondker, M. and Islam, M. S. 2012. Limnology of a conserved man-made lake in Bangladesh. I. physical and chemical factors. Dhaka Univ. J. Biol. Sci. 21(2): 131-140.

Bergins, B. 1949. Zur Lomnologe der seen sudostlent lend. Schweigh. Hydrobiologia 2(11): 583-607.

Clegg, J. 1974. Freshwater life. Frederick Worne and Co. Ltd. Dondin, 283 pp.

Das, T., Pathak, K. and Devi, M. B. 2011. Phytoplankton and Zooplankton Communities of an oxbow lake in valley, Assam, Assam University. Journal of Science and Technology. 7(1): 67 - 75.

Hossain, M. Z., Kabir, G. M. A. and Quraishi, S. B. 2010. Contamination of Dhanmondi and Gulshan lake waters with some metals and inorganic pollutants. Bang. J. Academy of Science, 34(1): 89-93.

Islam, M. A., Chowdhury, A. H. 2013. Limnological status of Trimohini beel of Rajshahi, Bangladesh. J. Asiat. Soc. Bangladesh, Sci., 39(2): 173-182.

Islam, M. A., Chowdhury, A. H. and Zaman, M. 2001. Limnology of fish ponds in Rajshahi, Bangladesh. Ecology \& Environment, 7(1): 1-7.

Islam, A. K. M. N. and Saha, J. K. 1975. Limnological studies of Ramna lake in Dhaka. Dhaka Univ. Stud., B. $23: 39$ - 46.

Khondker, M., Alfasane, M. A., Goni, M. A. and Islam, M. S. 2012. Limnological notes on Ramsagar, Dinajpur, Bangladesh. Bangladesh J. Bot., 41(1): 119-121.

Khondker, M., Alfasane, M. A., Islam, M. S., Bhuiyan, M. A. H. and Goni, A. 2010. Limnology of lake Bogakaine, Bandarban. Bangladesh J. Bot., 39(2): 153-159.

Mohuya, F. A., Bhuiyan, R. H. and Hoque, S. 2010. Heavy metal contamination in Gulshan-Baridhara lake, Dhaka. Dhaka Univ. J. Biol. Sci. 19 (1): 53-61.

Rahman, M. S. 1992. Water Quality Management in Aquaculture, BRAC prokashana, Mohakhali, Dhaka 1212, Bangladesh, 84 pp.

Singh, A., Chandra, S. and Tomar, P. K. 2012. Assessment of Water Quality Values in Porur Lake Chennai, Hussain Sagar Hyderabad and Vihar Lake Mumbai, India. Chemical Science Transactions, 1(3): 508 - 515.

Swingle, H. S. 1967. Standardization of chemical analysis for water and pond muds. FAO Fish. Rep. 4(44): 397-421. 